PNNL-13326

\title{
Groundwater Sampling and Analysis Plan for the 100-BC-5 Operable Unit
}

M. D. Sweeney

September 2000

RECEIVED

OCT 042000

OSTI

Prepared for

the U.S. Department of Energy

under Contract DE-AC06-76RL01830

Pacific Northwest National Laboratory

Richland, Washington 99352 



\section{DISCLAIMER}

This report was prepared as an account of work sponsored by an agency of the United States Government. Neither the United States Government nor any agency thereof, nor any of their employees, make any warranty, express or implied, or assumes any legal liability or responsibility for the accuracy, completeness, or usefulness of any information, apparatus, product, or process disciosed, or represents that its use would not infringe privately owned rights. Reference herein to any specific commercial product, process, or service by trade name, trademark, manufacturer, or otherwise does not necessarily constitute or imply its endorsement, recommendation, or favoring by the United States Government or any agency thereof. The views and opinions of authors expressed herein do not necessarily state or reflect those of the United States Government or any agency thereof. 


\section{DISCLAIMER}

Portions of this document may be illegible in electronic image products. Images are produced from the best available original document. 


\section{Contents}

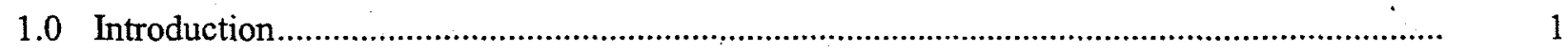

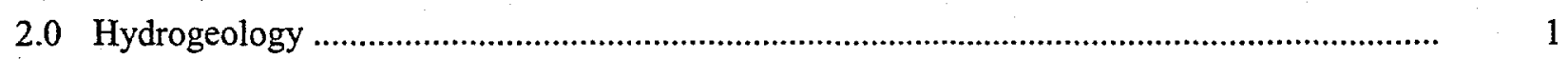

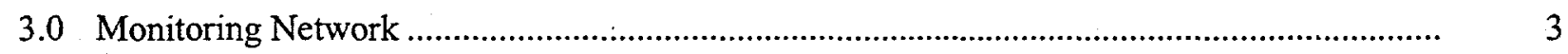

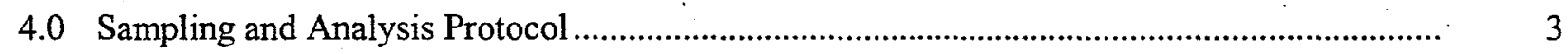

5.0 Quality Assurance and Quality Control ....................................................................

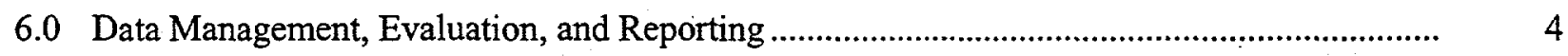

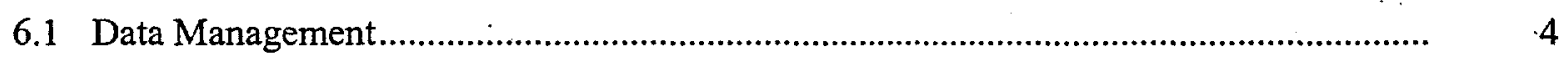

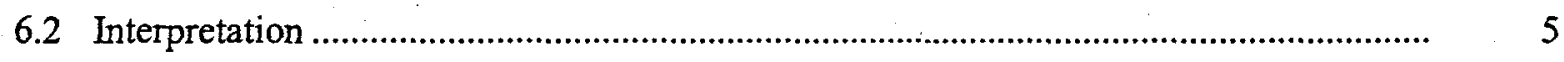

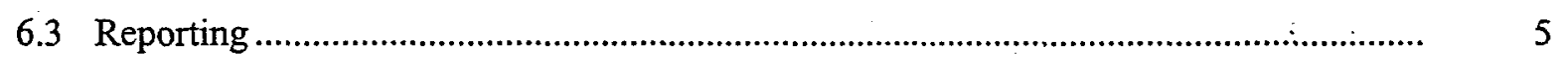

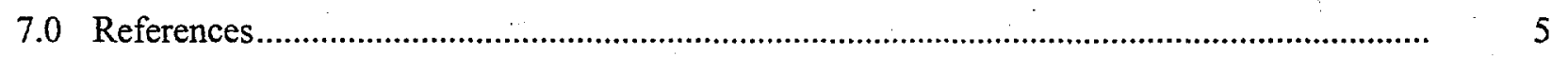

Appendix A - Federal Facility Agreement and Consent Order Change

Control Form M-16-99-03 .................................................................................. A.1

\section{Figure}

$1 \quad 100-B, C$ Groundwater Monitoring Network. 


\subsection{Introduction}

The purpose of this plan is to describe groundwater sampling and analysis for the Comprehensive Environmental Response, Compensation, and Liability Act (CERCLA) in the 100-BC-5 Operable Unit. The plan describes the well network, constituents analyzed, sampling protocol, and reporting and quality assurance requirements. Sampling and analysis requirements for this Operable Unit are specified in the change control form to the Federal Facility Agreement and Consent Order (Appendix A). The 100-BC-5 Operable Unit is the groundwater/surface water operable unit associated with past nuclear reactor operations in the 100-B,C Area of the U.S. Department of Energy's (DOE's) Hanford Site. The operable unit includes the groundwater below the source operable units $(100-\mathrm{BC}-1$ through -4$)$ plus the adjacent groundwater, surface water, sediments and aquatic biota impacted by 100-B,C Area operations (DOE/RL-90-08).

The 100-B,C Area (Figure 1) is the reactor area farthest upstream along the Columbia River. B Reactor was placed into service in 1944 and operated until 1968. C Reactor operated from 1952 to 1969. The B and C Reactors used a single-pass system for cooling water (i.e., cooling water passed through the reactor and was discharged to the Columbia River). Groundwater contaminants include strontium-90 and tritium. Chromium and nitrate are elevated locally.

\subsection{Hydrogeology}

The geology of the 100-B,C Area is described in detail in Conceptual Site Models for Groundwater Contamination at 100-BC-5, 100-KR-4, 100-HR-03, and 100-FR-3 Operable Units (BHI-00917). In general, the stratigraphy beneath the 100-B,C Area consists of the Hanford and Ringold Formations. The thickness of the Hanford formation is uncertain because the contact between it and the underlying Ringold Formation is not well defined. The Hanford formation, a gravel-dominated sequence with sandy and silty intervals, was reported to range from $14 \mathrm{~m}$ near the Columbia River to over $30 \mathrm{~m}$ thick in the southern part of the 100-B,C Area (Newcomb et al. 1972, WHC-SD-EN-TI-133). The Ringold Formation in the 100-B,C Area includes Unit $\mathrm{E}$ and the underlying paleosols and overbank deposits (BHI-00917, WHC-SD-EN-TI-133). Unit E, which varies in thickness across the 100-B,C Area is dominated by silty, sandy gravel with subordinate sand- and silt-dominated interbeds.

The unconfined aquifer beneath the 100-B,C Area lies within the silt, sand, and gravels belonging primarily to the Ringold Formation and is $\sim 34 \mathrm{~m}$ thick. The upper portion of the unconfined aquifer.lies locally within the lowermost Hanford formation. The top of the paleosols and overbank deposits of the Ringold Formation form the bottom of the unconfined aquifer. The depth to the water table varies from $<1 \mathrm{~m}$ near the Columbia River to $<30 \mathrm{~m}$ farther inland. Local confined aquifers lie within the Ringold Formation between the paleosol/overbank deposits and the top of the basalt. 


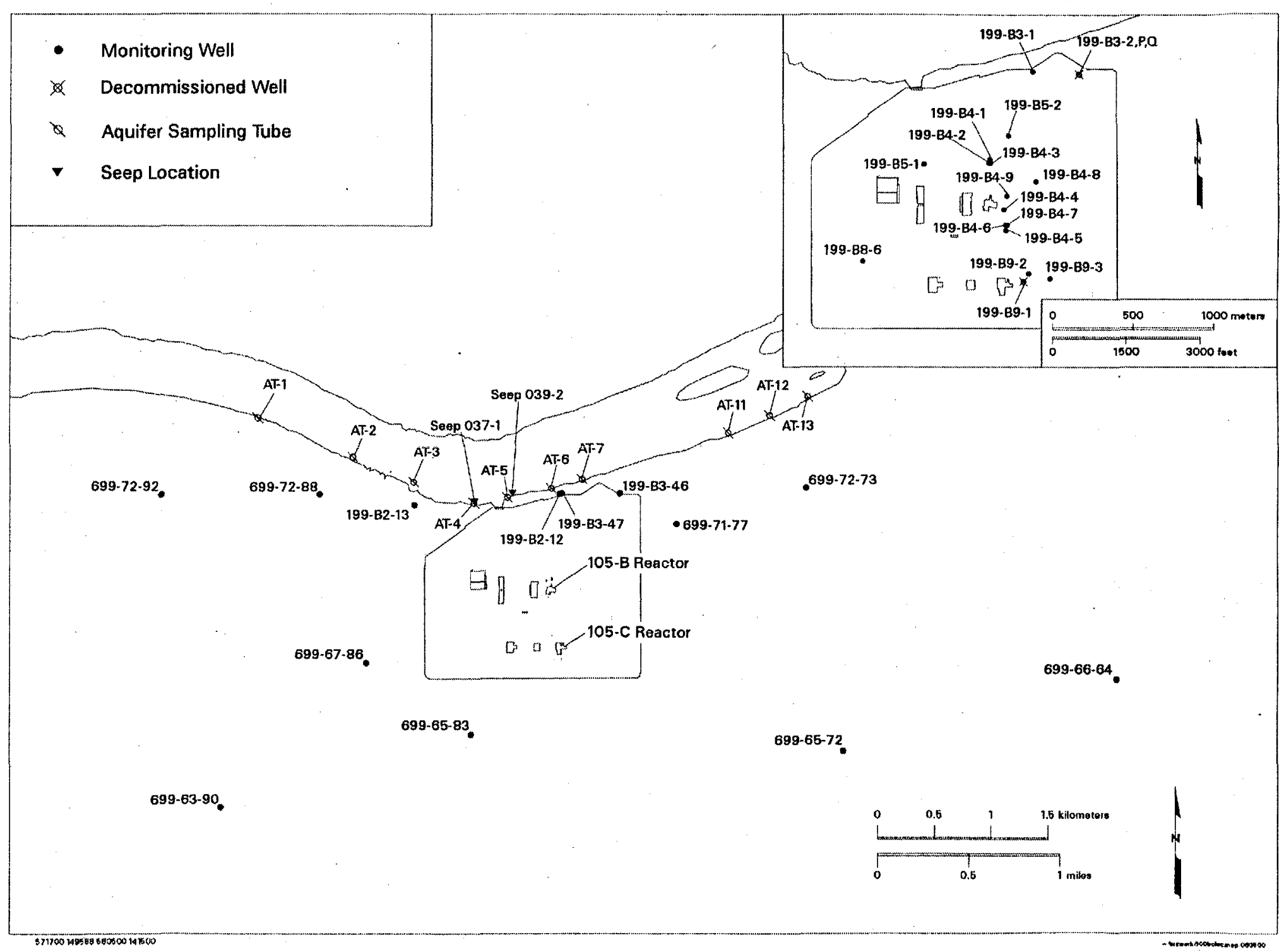

Figure 1. $100-\mathrm{B}, \mathrm{C}$ Groundwater Monitoring Network 
River-stage fluctuations dominate groundwater flow beneath the 100-B,C Area. The direction of groundwater flow within the unconfined aquifer is generally north toward the Columbia River. However, the flow direction periodically shifts to the southeast when river stage is high.

During the high-river stages, the groundwater gradient has been estimated to be 0.0009 with a gradient to the northeast. The low-river gradient for the $100-\mathrm{B}, \mathrm{C}$ Area is estimated to be 0.001 . Hydraulic conductivity of the Hanford formation in the 100-B,C Area ranges from 4.3 to $17 \mathrm{~m} / \mathrm{d}$ (BHI-00917). Using this range for hydraulic conductivity, a 0.0009 summer gradient, a 0.001 winter gradient, and an estimated effective porosity of 0.2 , the groundwater-flow velocity ranges from 0.02 to $0.08 \mathrm{~m} / \mathrm{d}$ in the summer and 0.02 to $0.09 \mathrm{~m} / \mathrm{d}$ in the winter.

\subsection{Monitoring Network}

The 100-BC-5 groundwater-monitoring network wells are shown in Figure 1 and are listed in Appendix A. The form in Appendix A also lists the specific constituents monitored at each well and the frequency of sampling. Additional constituents may be sampled at these wells for the requirements of the Atomic Energy Act of 1954 ("surveillance monitoring"), or for the requirements of the Integrated Monitoring Program (PNNL-11989, or the most recent edition).

Groundwater near the Columbia River is sampled annually in the late fall via aquifer sampling tubes and riverbank seeps. The sampling tubes are polyethylene tubes that were driven into the aquifer at locations near the low-water shoreline. Seeps are locations where groundwater discharges above the river level.

\subsection{Sampling and Analysis Protocol}

Monitoring for the 100-BC-5 Operable Unit is part of the Hanford Groundwater Monitoring Project. Procedures for groundwater sampling, documentation, sample preservation, shipment, and chain-ofcustody requirements are described in Pacific Northwest National Laboratory (PNNL) or subcontractor manuals (currently a Waste Management Northwest procedure manual) and in the quality assurance plan (a PNNL internal document). Samples generally are collected after three casing volumes of water have been purged from the well or after field parameters ( $\mathrm{pH}$, temperature, specific conductance, and turbidity) have stabilized. For routine groundwater samples, preservatives are added to the collection bottles before their use in the field. Samples to be analyzed for metals are usually filtered in the field so that results represent dissolved metals. 
Procedures for field measurements are specified in the subcontractor's or manufacturer's manuals. Analytical methods are specified in contracts with laboratories, and most are standard methods from Test Methods for Evaluating Solid Wastes, Physical/Chemical Methods (SW-846). Alternative procedures meet the guidelines of SW-846, Chapter 10. Analytical methods are described in Gillespie (1999).

\subsection{Quality Assurance and Quality Control}

The groundwater monitoring project's quality assurance/quality control (QA/QC) program is designed to assess and enhance the reliability and validity of groundwater data. The primary quantitative measures or parameters used to assess data quality are accuracy, precision, completeness, and the method detection limit. Qualitative measures include representativeness and comparability. Goals for data

representativeness for groundwater monitoring projects are addressed qualitatively by the specification of well locations, well construction, sampling intervals, and sampling and analysis techniques in the groundwater monitoring plan for each Resource Conservation and Recovery Act (RCRA) facility. Comparability is the confidence with which one data set can be compared to another. The QC parameters are evaluated through laboratory checks (e.g., matrix spikes, laboratory blanks), replicate sampling and analysis, analysis of blind standards and blanks; and interlaboratory comparisons. Acceptance criteria have been established for each of these parameters, based on guidance from the U.S. Environmental Protection Agency (OSWER-9950.1), and are specified in the project's quality assurance manual. When a parameter is outside the criteria, corrective actions are taken to prevent a future occurrence and affected data are flagged in the database.

\subsection{Data Management, Evaluation, and Reporting}

This chapter describes how groundwater data are stored, retrieved, evaluated, interpreted, and reported.

\subsection{Data Management}

The contract laboratories report analytical results electronically. The results are loaded into the Hanford Environmental Information System (HEIS) database. Field-measured parameters are entered manually or through electronic transfer. Paper data reports and field records are considered to be the record copies and are stored at PNNL.

The data undergo a validation/verification process according to a documented procedure, as described in the project QA plan. QC data are evaluated against the criteria listed in the project QA plan and data flags are assigned when appropriate. In addition, data are screened by scientists familiar with the . 
hydrogeology of the unit, compared to historical trends or spatial patterns, and flagged if they are not representative. Other checks on data may include comparison of general parameters to their specific counterparts (e.g., conductivity to ions; gross alpha to uranium), calculation of charge balances, and comparison of calculated versus measured conductivity. If necessary, the laboratory may be asked to check calculations or reanalyze the sample, or the well may be resampled.

\subsection{Interpretation}

After data are validated and verified, the acceptable data are used to interpret groundwater conditions at the site. Interpretive techniques include:

- Hydrographs: graph water levels versus time to determine decreases, increases, seasonal, or manmade fluctuations in groundwater levels.

- Water-table maps: use water-table elevations from multiple wells to construct contour maps to estimate flow directions. Groundwater flow is assumed to be perpendicular to lines of equal potential.

- Trend plots: graph concentrations of chemical or radiological constituents versus time to determine increases, decreases, and fluctuations. May be used in tandem with hydrographs and/or water-table maps to determine if concentrations relate to changes in water-level or in groundwater flow directions.

- Plume maps: map distributions of chemical or radiological constituents areally in the aquifer to determine extent of contamination. Changes in plume distribution over time aid in determining movement of plumes and direction of flow.

- Contaminant ratios: can sometimes be used to distinguish between different sources of contamination.

\subsection{Reporting}

Interpretations of data for the 100-BC-5 Operable Unit are reported annually along with the rest of the Groundwater Project (e.g., PNNL-13116).

\subsection{References}

Atomic Energy Act of 1954, as amended, Ch. 1073, 68 Stat. 919, 42 USC 2011 et seq. 
BHI-00917. 1996. Conceptual Site Models for Groundwater Contamination at 100-BC-5, 100-KR-4, 100-HR-03, and 100-FR-3 Operable Units. R. E. Peterson, R. F. Raidel, and C. W. Denslow, Bechtel Hanford, Inc., Richland, Washington.

Comprehensive Environmental Response, Compensation, and Liability Act. 1980. Public Law 96-150, as amended, 94 Stat. 2767, USC 9601 et seq.

DOE/RL-90-08. 1992. Remedial Investigation/Feasibility Study Work Plan for the 100-BC-5 Operable Unit, Hanford Site, Richland, Washington. U.S. Department of Energy, Richland Operations Office, Richland, Washington.

Gillespie, B. M. 1999. “Appendix C, Analytical Methods." In PNNL-12086, Hanford Site Groundwater Monitoring for 1998, Pacific Northwest National Laboratory, Richland, Washington.

Newcomb, R. C., J. R. Strand, and F. J. Frank. 1972. Geology and Ground-Water Characteristics of the Hanford Reservation of the U.S. Atomic Energy Commission, Washington. Professional Paper 717, U.S. Geological Survey, Washington, D.C.

OSWER-9950.1. 1986. Resource Conservation and Recovery Act (RCRA) Groundwater Monitoring Technical Enforcement Guidance Document (TEGD). U.S. Environmental Protection Agency, Washington, D.C.

PNNL-1 1989, Rev. 1. 1999. Integrated Monitoring Plan for the Hanford Groundwater Monitoring Project. M. J. Hartman, P. E. Dresel, D. R. Newcomer, and E. C. Thornton, Pacific Northwest National Laboratory, Richland, Washington.

PNNL-13116. 2000. Hanford Site Groundwater Monitoring for Fiscal Year 1999. M. J. Hartman, L. F. Morasch, and W. D. Webber (eds.), Pacific Northwest National Laboratory, Richland, Washington.

Resource Conservation and Recovery Act. 1976. Public Law 94-580; as amended, 90 Stat. 2795, 42 USC 6901 et seq.

SW-846. 1986. Test Methods for Evaluating Solid Wastes, Physical/Chemical Methods, $3^{\text {rd }}$ ed. Office of Solid Waste and Emergency Response, U.S. Environmental Protection Agency, Washington, D.C.

Washington State Department of Ecology, U.S. Environmental Protection Agency, and U.S. Department of Energy. 1998. Hanford Federal Facility Agreement and Consent Order. Document No. 89-10, Rev. 5 (The Tri-Party Agreement), Olympia, Washington.

WHC-SD-EN-TI-133. 1993. Geology of the 100-B/C Area, Hanford Site, South-Central Washington. J. W. Lindberg, Westinghouse Hanford Company, Richland, Washington. 


\section{Appendix A}

\section{Federal Facility Agreement and Consent Order}

Change Control Form M-15-99-03 


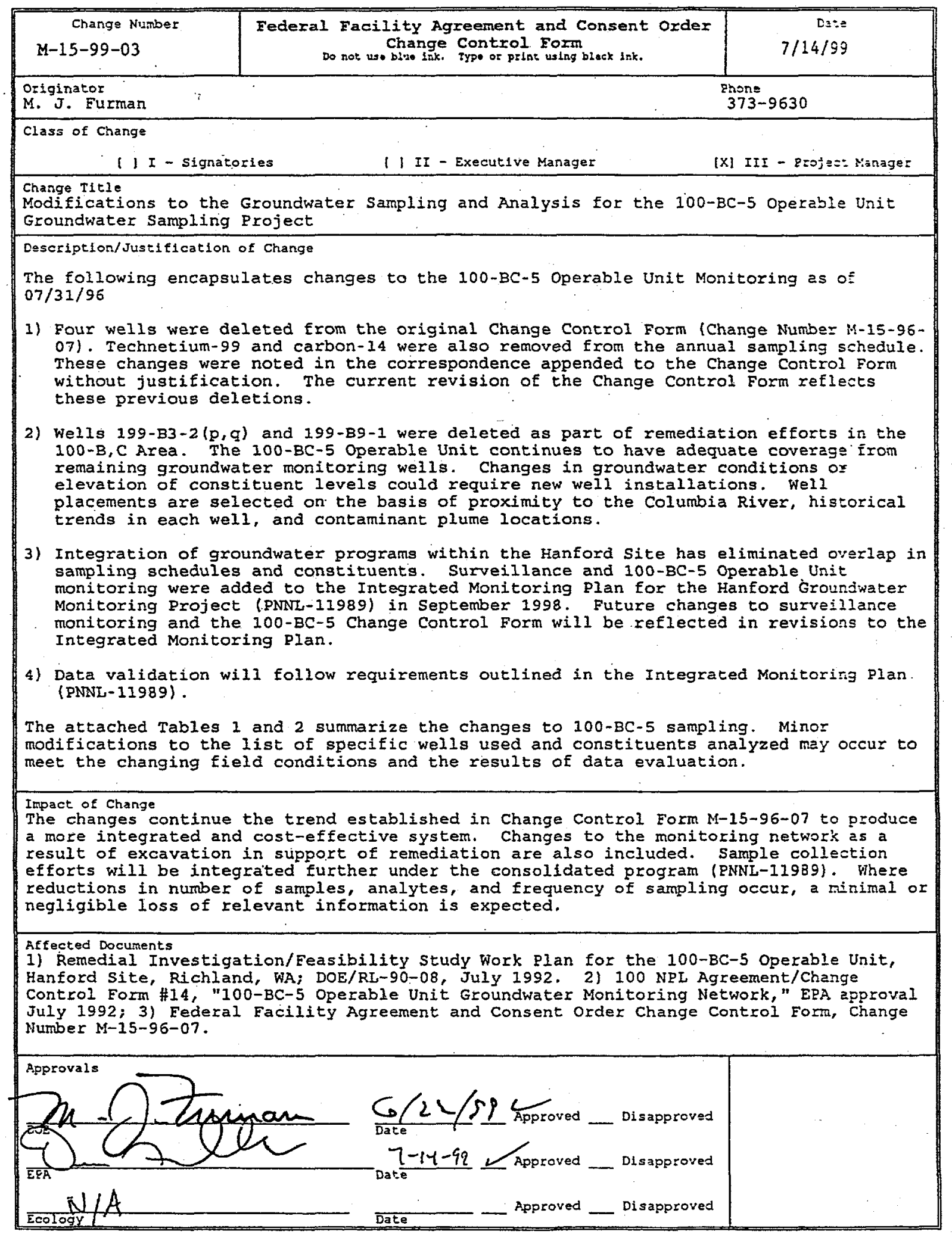


Table 1. Sampling and Analysis 3chedule for 100-BC-5 Groundwater Project

\begin{tabular}{|c|c|c|c|c|}
\hline Well Number & $\begin{array}{l}\text { Facility } \\
\text { Monitored/Purpose }\end{array}$ & Schedule & Program & Change \\
\hline $199-\mathrm{B2}-12$ & $\begin{array}{l}\text { 116-B-11 Retention } \\
\text { Basin }\end{array}$ & A & BCLEI & None \\
\hline $199-\mathrm{B} 3-1$ & $\begin{array}{l}\text { 116-B-11 Retention } \\
\text { Basin }\end{array}$ & $\bar{A}$ & BCLEI & None \\
\hline $199-\mathrm{B} 3-2(\mathrm{p}, \mathrm{q})$ & 116-B-11 Trench & $N / A$ & $\mathrm{~N} / \mathrm{A}$ & Decominissioned \\
\hline $199-\mathrm{B} 3-46$ & $116-\mathrm{C}-1$ Trench & $A$ & BCLEI & None \\
\hline $199-83-47$ & $\begin{array}{l}\text { 116-B-11 Retention } \\
\text { Basin }\end{array}$ & A & BCLEI & None \\
\hline $199-84-1$ & $116-B-5$ Crib & $2-0$ & BCLEI & None \\
\hline $199-\mathrm{BA}-2$ & $116-8-5$ Crib & $\mathrm{A}$ & $s$ & None \\
\hline $199-B A-3$ & $116-\mathrm{B}-5 \mathrm{crib}$ & $N / A$ & BCLFI & Reserve \\
\hline $199-\mathrm{B} 4-4$ & $\begin{array}{l}\text { B Reactor Builaing } \\
\text { Effluent Disposal }\end{array}$ & $2-E$ & BCLFI & None \\
\hline $199-84-5$ & $\begin{array}{l}\text { In situ vitrification } \\
\text { Test/116-B-6A }\end{array}$ & $2-E$ & BCLFI & None \\
\hline $199-B 4-6$ & $\begin{array}{l}\text { In situ vitrification } \\
\text { Test/116-B-6A }\end{array}$ & $\mathrm{N} / \mathrm{A}$ & BCLFI & Reserve \\
\hline $199-B 4-7$ & $\begin{array}{l}\text { In situ Vitrification } \\
\text { Test/116-B-6A }\end{array}$ & $2-E$ & BCLFI & None \\
\hline $199-\mathrm{B} 5-1$ & $\begin{array}{l}\text { 183-B Water Treatment } \\
\text { plant }\end{array}$ & A & BCLFI & None \\
\hline $199-\mathrm{B} 5-2$ & $\begin{array}{l}\text { Liquid Effluent } \\
\text { Disposal Crib }\end{array}$ & A & BCLFI & None \\
\hline $199-\mathrm{B} 8-6$ & 105-B Burial Ground & $2-E$ & BCLFI & None \\
\hline $199-B 9-1$ & Reactor "pluto" crib & $\mathrm{N} / \mathrm{A}$ & $\mathrm{N} / \mathrm{A}$ & Decommissioned \\
\hline $199-\mathrm{B} 9-2$ & Reactor "pluto" crib & $2-E$ & BCLFI/S & None \\
\hline $199-B 9-3$ & Reactor "pluto" crib & $2-0$ & BCLFI & None \\
\hline $699-63-90$ & Background & A & $\mathrm{s}$ & None \\
\hline $699-65-72$ & Background & $2-0$ & BCLFI/S & None \\
\hline $699-65-83$ & Background & $2-E$ & BCLFI & None \\
\hline $699-66-64$ & Background & $2-0$ & BCLFI/S & None \\
\hline $699-67-86$ & Background & $2-E$ & BCLFI & None \\
\hline $699-72-73$ & Background & A & BCLEI/S & None \\
\hline $699-72-88$ & Background & A & $s$ & None \\
\hline $699-72-92$ & Background & $2-E$ & BCLFI & None \\
\hline Seep 037-1 & $\begin{array}{l}\text { Area/shoreline } \\
\text { exposure }\end{array}$ & A & BCLEI & None \\
\hline Seep $039-2$ & $\begin{array}{l}\text { Area/shoreline } \\
\text { exposure. }\end{array}$ & A & BCLFI & None \\
\hline \multicolumn{5}{|c|}{$\begin{array}{l}\text { Notes: 2-E = biennial sampling, even years (starting 1998), } \mathrm{A}=\text { annual } \\
\text { sampling, } 2-0=\text { biennial sampling, odd years (starting 1997), } \mathrm{S}= \\
\text { Surveillance Monitoring, BCLFI }=100-B C-5 \text { Limited Field Investigation, } \\
\mathrm{N} / \mathrm{A}=\text { not applicable/decomnissioned well }\end{array}$} \\
\hline
\end{tabular}


Table 2. Analysis sulte codes for the 100-BC-5 Groundwatex Project

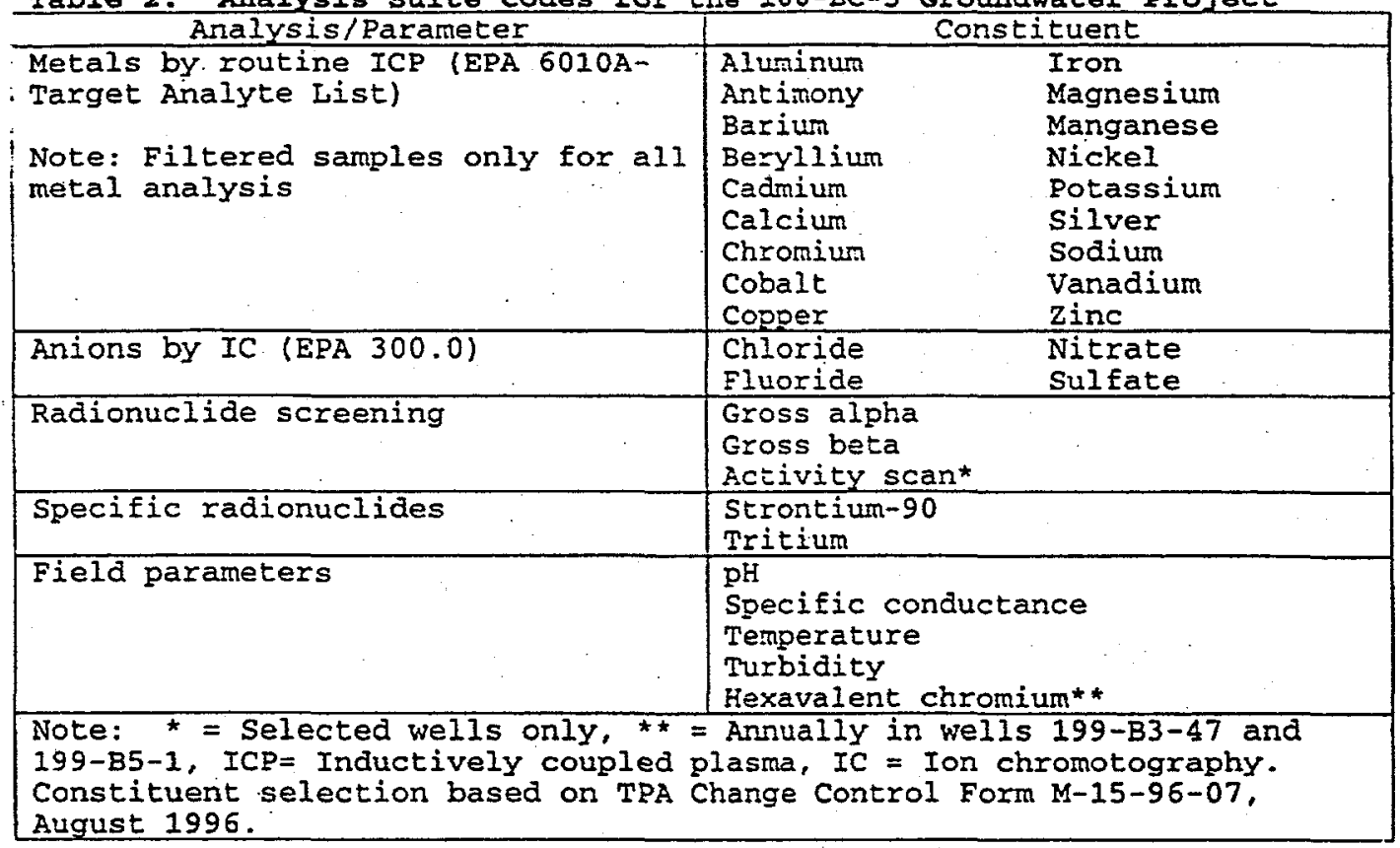




\section{Distribution}

No. of

Copies

ONSITE

2 DOE Richland Operations Office

\begin{abstract}
M. J. Furman
\end{abstract}
A. C. Tortoso

A5-13

H0-12

U.S. Environmental Protection Agency

D. A. Faulk

B5-01
No. of

Copies

Washington State Department of Ecology

W. W. Soper

B5-18

15 Pacific Northwest National Laboratory

M. J. Hartman

K6-96

S. P. Luttrell

K6-96

M. D. Sweeney (5)

K6-81

D. Vela

K6-96

Information Release Office (7)

K1-01

Distr.1 